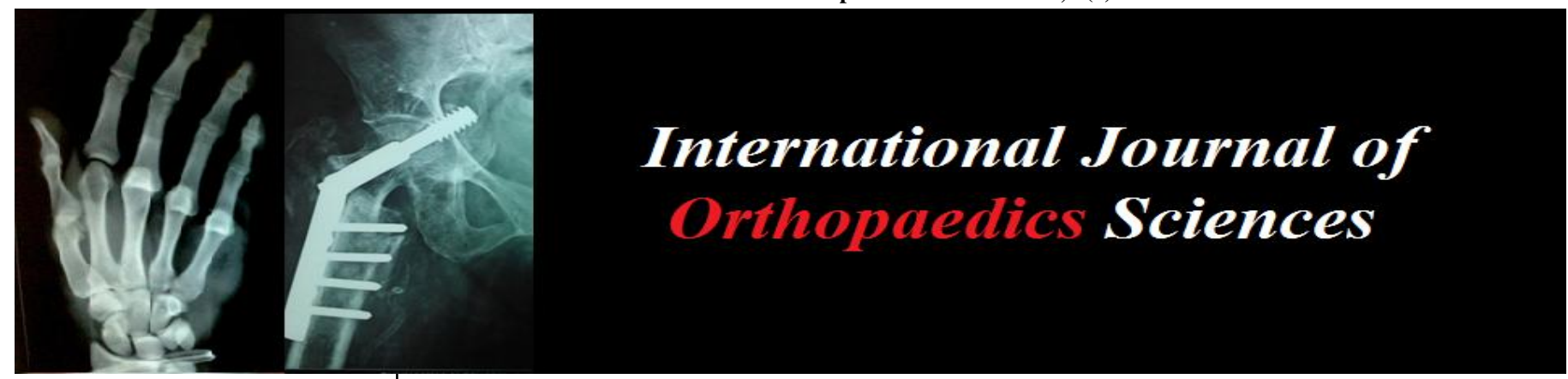

ISSN: $2395-1958$

IJOS 2018; 4(1): 585-589

(C) 2018 IJOS

www.orthopaper.com

Received: 04-11-2017

Accepted: 05-12-2017

Dr. Vidyadhar S Donimath Associate Professor,

Department of Orthopaedics,

Karnataka Institute of Medical

Sciences, Hubli, Karnataka,

India

Dr. AE Chandan

Junior Resident,

Department of Orthopaedics,

Karnataka Institute of Medical

Sciences, Hubli, Karnataka,

India

Dr. SR Sandeep

Junior Resident,

Department of Orthopaedics,

Karnataka Institute of Medical

Sciences, Hubli, Karnataka,

India

Mrutyunjay Battur

Junior Resident,

Department of Orthopaedics,

Karnataka Institute of Medical

Sciences, Hubli, Karnataka,

India

\section{A prospective study on functional outcome of distal tibia fractures treated with minimally invasive percutaneous plate osteosynthesis}

\author{
Dr. Vidyadhar S Donimath, Dr. AE Chandan, Dr. SR Sandeep and \\ Mrutyunjay Battur
}

DOI: https://doi.org/10.22271/ortho.2018.v4.i1i.84

\section{Abstract}

Distal tibial fractures are very commonly encountered by orthopaedic surgeons. Fractures of distal tibia are among the most perplexing injuries. Distal tibial fractures are difficult to manage due to its poor blood supply and limited soft tissue. Soft tissue injury component is a major concern among these fractures and may result in serious complications and disability ${ }^{[1]}$. High energy motor vehicle accidents are the common cause ${ }^{[2]} .0 .7 \%$ is the incidence of distal tibia fractures and it accounts to about $10-13 \%$ of all tibial fractures ${ }^{[3]}$. The aim of this study was to evaluate the functional outcome and to study major complications in KIM's hospital.

Materials and Methods: A prospective study which was carried out from October 2015 to September 2017 in Karnataka Institute of Medical Sciences, Hubbali, and Karnataka State, India. In this study period, cases of distal tibial fractures were treated by open reduction and internal fixation using MIPPO. All patients with age $>18$ years, closed fractures without intra-articular extension and Gustillo type 1 fractures were included. Pathological fractures and grade 2 and above were excluded.

Results: In our series of 18 cases, there were 14 men and 4 women, with average age of 40.3 years. Sixteen $(88.8 \%)$ cases were admitted due to RTA and with slight predominance of left side. All fractures healed with good functional outcome. Mean union time was 22.6 weeks. 14 cases showed good ankle function outcome and 3 showed fair ankle function outcome according to Merchant and Dietz criteria. There was 1 case of superficial infection, treated successfully with antibiotics.

Conclusion: The strategy of biological osteosynthesis with a bridge plating is less invasive, with fewer soft tissue impingement and improved cosmoses and convenient for removal.

Keywords: Tibia fracture, Surgery, MIPPO technique, locking plate

\section{Introduction}

Tibia is one of the most commonly fractured long bone of the body. $0.7 \%$ is the incidence of distal tibia fractures and it accounts to about $10-13 \%$ of all tibial fractures ${ }^{[3]}$. Fractures of distal tibia are among the most perplexing injuries. High energy motor vehicle accidents are the most common cause ${ }^{[2]}$. The management of distal tibia fractures is complex because of its unique anatomical characteristics of subcutaneous location with precarious blood supply, leading to postoperative complications and poor outcome. Therefore, the treatment of distal tibia fractures remains challenging. The distal tibialfracture should be treated as a type of "open fracture" due to its poor soft tissue envelope which will have been damaged from the injury, even without an open wound.

A variety of treatment methods have been suggested for these injuries, including non-operative treatment, intramedullary nailing and plate fixation. Non-operative treatment can be an option for certain fracture patterns but may be complicated by loss of reduction and subsequent malunion ${ }^{[4]}$. Distal tibial fractures can be treated with open reduction and fixation ${ }^{[5-8]}$. Less favorable environment is caused by extensive soft tissue damage and devitalisation leading to infection and postoperative ankle stiffness ${ }^{9}$.Therefore intramedullary nailing, percutaneous plating have been chosen as the standard treatment for distal tibia fractures. The intramedullary nailing system needs extensive surgical dissection with the sparing of the extraosseous blood supply and supports the tibia in a load-sharing manner.

\section{Dr. AE Chandan}

Junior Resident,

Department of Orthopaedics,

Karnataka Institute of Medical

Sciences, Hubli, Karnataka,

India 
But it has its own complications. Preservation of the periosteal blood supply around the fracture site is brought about by locked plating system. Thus they are indicated mainly in management of fracture in osteoporotic bone and in periarticular fracture patterns. Preservation of vascularity of fracture fragments, fracture haematoma and minimal soft tissue damage favour minimally invasive percutaneous plating for distal tibia fractures.

With this background, current study focuses onthe functional outcome and the various complications associated with it.

\section{Patients and methods}

A prospective study was conducted from October 2015 to September 2017 in Karnataka Institute of Medical Sciences, Hubbali, and Karnataka. In this study period, 18 cases of distal tibial fractures were surgically managed by MIPPO. All patients with skeletal maturity i.e. age $>18$ years, closed fractures without intra-articular extension and Gustillo type 1 fractures were included. Intra articular fractures, pathological fractures and Gustillo type II or more open fractures were excluded. AO/OTA classification system was used to classify fractures ${ }^{[10]}$.

Preoperative evaluation was done as history, examination, complete preoperative radiographic assessment doneas Antero Posterior (AP) view and lateral view of the affected leg. Analgesics were given. Routine investigations were done, and informed consent and physician reference for fitness were obtained. The patient were initially stabilized with calcaneal skeletal traction until the subsidence of the soft tissue injury i.e. decrease in the swelling especially Tscherne Classification type 2 . Following which the patient was operated.

\section{Procedure}

Intravenous antibiotics were started peri-operatively and then after induction with spinal anaesthesia patient was positioned supine on operation table with a thigh tourniquet. In cases associated with fibular fracture it was fixed first using a onethird tubular or recon plate, which was useful in maintaining the length, alignment and subsequent reduction of the tibial fracture. Once lateral malleolus plating is done the distal tibial LCP was tunneled subcutaneously, through limited skin incisions avoiding injury to the saphenous nerve and vein. Initial reduction and location of plate was checked under image intensifier. Interfragmentary compression was achieved with cortical screws placed through the plate. Following inter fragmentary compression a mechanically stable construct was made by use of locking screws. Wound closure was done in layers without a suction drain. Following operation compression bandage was given, and limb was elevated

\section{Follow Up}

Postoperative splinting was not used routinely. Postoperative knee and ankle bending exercises were initiated POD 1. Non weight bearing mobilization by walker was started on POD 3 . Partial weight bearing allowed after 6-8 weeks. Complete weight bearing mobilization was permitted only after clinicoradiological union at 12 to 14 weeks. Clinical and radiological follow up of the operated patients were done at consistent intervals.

\section{Results}

A total of 18 patients were included. Mean age of patients was 40.3 years. Fourteen patients were men and four were women. Left side was affected in eleven patients $(61.1 \%)$ and right side was affected in 07 patients $(38.9 \%)$. Most common mode of injury was road traffic accidents in 16 patients $(88.89 \%)$, fall in 1 patients $(5.56 \%)$ and assault in one patient $(5.56 \%)$.All fractures were classified according to AO/OTA classification of which 4 fractures were 43A1, 11 fractures were $43 \mathrm{~A} 2$ and 3 fractures were $43 \mathrm{~A} 3$. All fractures were closed. The soft tissue injury was graded according to Tscherene classification of which 10 fractures were type 0,6 were type 1 and another 2 were of type 2 injury.

All patients were operated within 7 days of admission. 17 patients were operated between 3-7 days of injury and one patient was operated 2 days after admission.

Follow up was done at 6 weekly interval for evaluation of clinico-radiological signs for union. Clinical union was defined as single stance, painless full weight-bearing on the healed fractured extremity. Radiological union was defined as evidence of bridging callus. Delayed union was labeled when patient does not met the above said criteria of union at nine months.

All fractures united in this study united between 16-24 weeks. The mean union time was 22.6 weeks.Infection occurred in one case which presented at $12^{\text {th }}$ month of follow up with signs of cellulitis, skin breakdown and sinus at implant site.

The minimum period of follow up in our study was 1 year ranging from 12 months to 16 months.

A clinical assessment of ankle function according to the criteria of Merchant and Dietz ${ }^{[11]}$ was determined for each ankle at the end of 1 year follow-up. It is a 100 point scale allotting 40 points for function, 40 for pain, 10 for gait and 10 points for range of motion at the ankle. A score of 85-100 represents an excellent result, 70-84 good result, 60-69 fair result and less than 60 poor results. 15 had good results and 3 had fair results.

Functional outcome was assessed based on Johner and Wruhs criteria $^{[12]}, 14$ had good outcome, 4 had fair outcome.

\section{Ankle Funct Ion According To the Criteria of Merchant and Dietz}

\begin{tabular}{|c|c|c|}
\hline Alignment & \multicolumn{2}{|c|}{ Mippo } \\
\hline & No Of Cases Percentage (\%) \\
\hline Excellent Results & 0 & 0.0 \\
\hline Good Results & 15 & 83.33 \\
\hline Fair Results & 03 & 16.67 \\
\hline Poor Results & 0 & 0.0 \\
\hline
\end{tabular}

\section{Functional Outcome Based On Johner and Wruhs Criteria}

\begin{tabular}{|c|c|c|}
\hline Outcome & \multicolumn{2}{|c|}{ Mippo } \\
\hline & No of Cases Percentage (\%) & 0.0 \\
\hline Excellent & 0 & 77.78 \\
\hline Good & 14 & 22.22 \\
\hline Fair & 4 & 0.0 \\
\hline Poor & 0 & \\
\hline
\end{tabular}

\section{Discussion}

The treatment of distal tibial fracture management remains a challenging topic because

1. High energy trauma.

2. Soft tissue injury around the fracture site.

Therefore appropriate preoperative planning is necessary in view of the associated soft tissue injury and minimizing the postoperative malalignment and soft tissue complication.

Our study comprised of 18 patients with closed extrarticular distal tibia treated with minimally invasive techniques based 
on soft tissue condition and fracture pattern. Fibula fracture was fixed based on intraoperative alignment of tibia fracture. Fibula was fixed only if reduction of tibia remained unacceptable or difficulty in achieving reduction with tibia fixation alone. The results were evaluated in terms of functional outcome and complications.

In our study we had 14 male and 4 female patients with 11 fractures occurring on left side and 7 on right side. The mean age of patients in our study was 40.3 years ranging from 2050 years. When analyzed, in study done by Guo J, et al ${ }^{[15]}$ in 2010the mean age of patients was 43 years. In another study Robinson C, et al ${ }^{[16]}$ it was 46 years.

The most common cause for these fractures in our study was road traffic accident (R.T.A). Majority of the studies show vehicular accidents as the common mode of injury followed by fall. Our study has also classified these fractures as in
Standard studies according to AO/OTA classification and soft tissue injury using Tscherene classification thus eliminating intra and inter observer variability.

We achieved union in all treated with MIPPO with mean union time of 22.6 weeks. Oh W, et al ${ }^{[33]}$ in their study, mean union time for these fractures treated with MIPPO was 15.2 weeks (range, 10-24 weeks). In study by Ronga M, et al ${ }^{[17]}$ they achieved union in all fractures by 24 weeks. In study by Borg $\mathrm{T}$ et al ${ }^{[18]}$, they achieved union in $90 \%$ of fractures within 24 weeks. The mean time for union in Collinge $\mathrm{C}$, et al ${ }^{[19]}$ study was 35 weeks but all fractures which were closed healed within 25 weeks.

The mean ankle evaluation score at the end of one year using Iowa ankle score by Merchant and Dietz ${ }^{[11]}$ was 78 (ranging from 63-82) and this corresponds to overall good result. $83.33 \%$ of the cases in our study had good results.
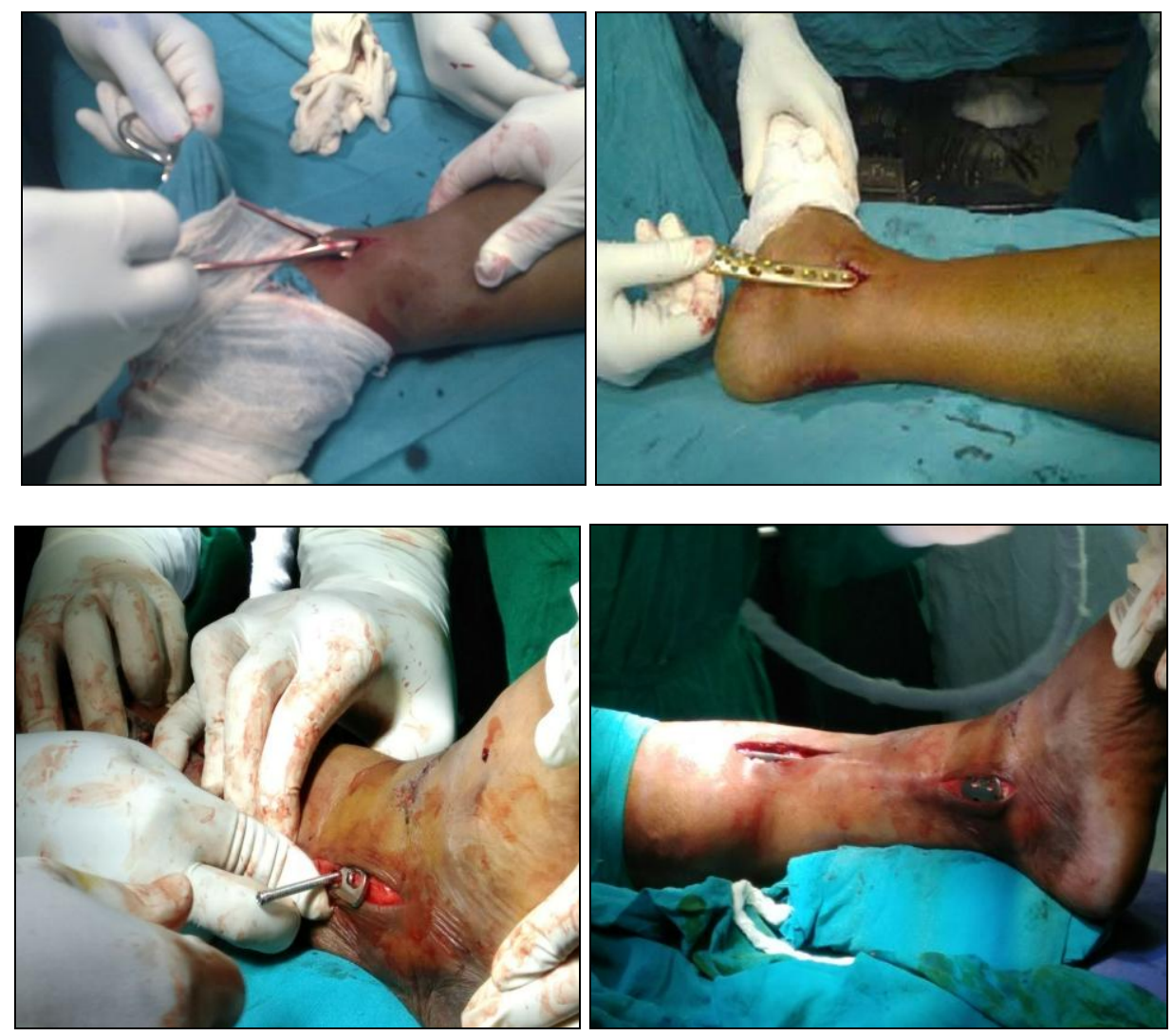

Operativre photographs

\section{Case 1}

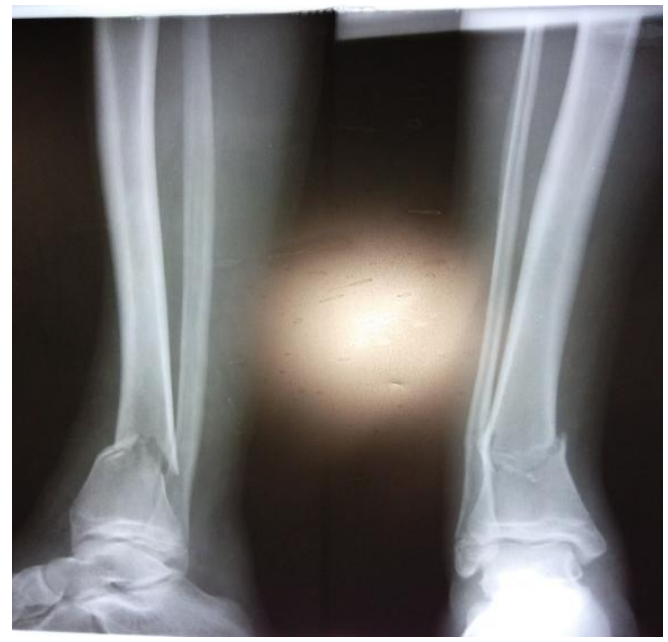

Pre op

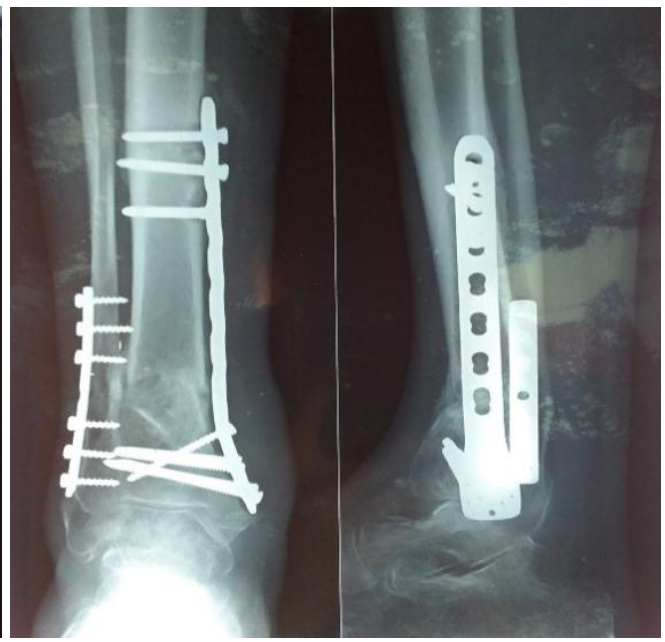

After fracture union 
Case 2
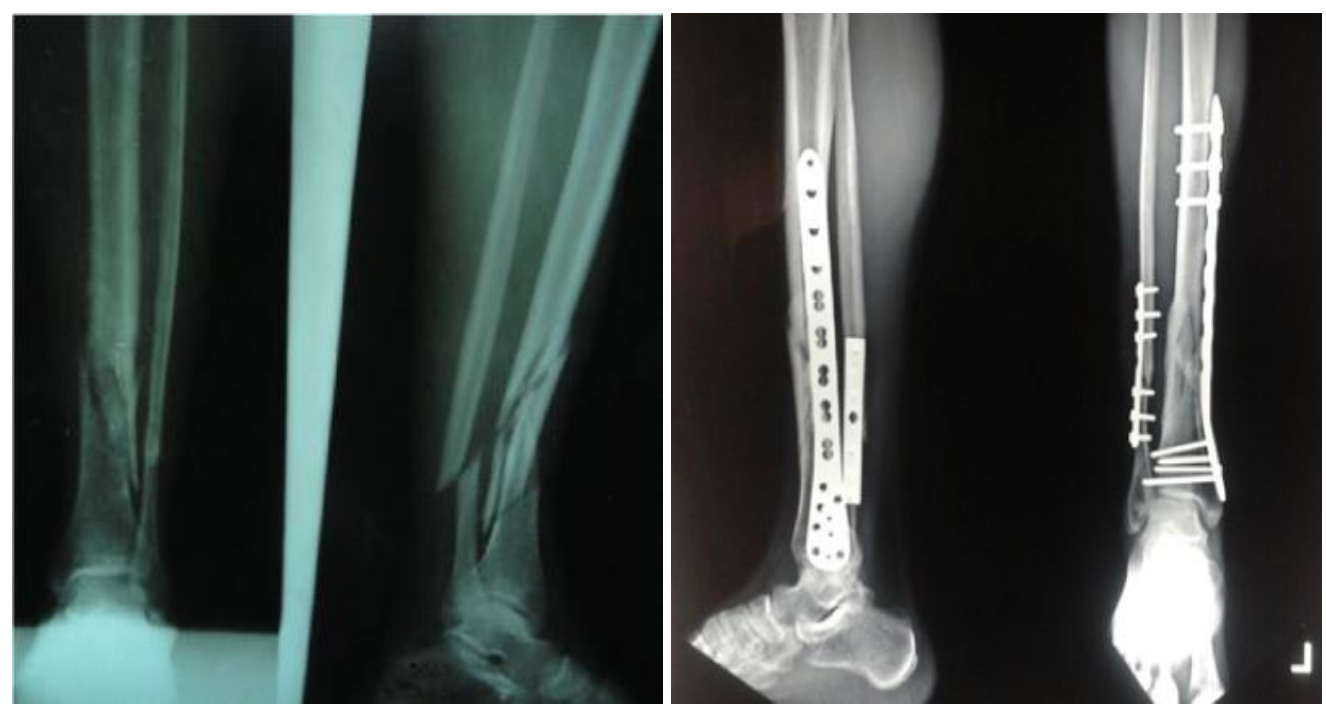

After fracture union

\begin{tabular}{|c|c|c|c|c|c|}
\hline $\begin{array}{l}\text { Study and } \\
\text { type of } \\
\text { fixation }\end{array}$ & $\begin{array}{c}\text { Total } \\
\text { number of } \\
\text { cases }\end{array}$ & $\begin{array}{l}\text { Mean union } \\
\text { time in weeks }\end{array}$ & $\begin{array}{l}\text { Follow up } \\
\text { period }\end{array}$ & Complications & Ankle function and outcome \\
\hline $\begin{array}{c}\text { Nork S, et al } \\
{[20]}\end{array}$ & 36 & $\begin{array}{c}23.5 \\
{[13-57 \text { Weeks] }}\end{array}$ & 2 YEARS & $\begin{array}{l}5 \% \text { of cases had deep infection/ no } \\
\text { cases had implant failure }\end{array}$ & $80 \%$ good results. \\
\hline $\begin{array}{l}\text { Ehlinger M, } \\
\text { et al }^{[23]}\end{array}$ & 51 & $\begin{array}{c}16 \\
{[10-30 \text { Weeks }]}\end{array}$ & 1 YEAR & $\begin{array}{l}2 \% \text { cases had deep infection/ no } \\
\text { cases of implant failure }\end{array}$ & $\begin{array}{c}\text { Good to fair results in most cases } \\
\text { with limitation of physical } \\
\text { activities }\end{array}$ \\
\hline Oh W, et al ${ }^{[33]}$ & 21 & $\begin{array}{c}16 \\
{[8-24 \text { Weeks }]}\end{array}$ & 1.8 YEAR & $\begin{array}{c}\text { No cases of infection/implant failure/ } \\
40 \% \text { cases had implant irritation }\end{array}$ & $\begin{array}{c}\text { Excellent to satisfactory results in } \\
\text { all cases }(80-100 \%)\end{array}$ \\
\hline $\begin{array}{l}\text { Collinge C, } \\
\text { et al }^{[38]}\end{array}$ & 36 & $\begin{array}{c}35 \\
{[12-112} \\
\text { Weeks] } \\
\end{array}$ & 1.5 YEARS & $\begin{array}{c}2 \text { cases each }(7 \%) \text { of loss of fixation } \\
\text { and deep infection }\end{array}$ & $\begin{array}{c}\text { Good to fair results in most cases } \\
\text { with limitation of physical } \\
\text { activities }\end{array}$ \\
\hline Guo J, et al ${ }^{[15]}$ & 41 & 17.66 & 1YEAR & $\begin{array}{l}\text { No cases had implant failure/ } \\
\text { infection }\end{array}$ & $\begin{array}{l}80 \% \text { good results and } 20 \% \text { fair } \\
\text { results }\end{array}$ \\
\hline Present study & 18 & 22.6 weeks & 1 YEAR & 1 case of infection & $\begin{array}{l}77.78 \% \text { good results and } 22.22 \% \\
\text { fair results }\end{array}$ \\
\hline
\end{tabular}

\section{Conclusion}

The surgical care of extra-articular distal tibia fractures is controversial. Most of these fractures are caused by high energy. An interval of 3-7 days between injury and surgery should be the protocol especially if plating using minimal invasive technique is planned so as to reduce the incidence of soft tissue complications associated with these fractures. Vigilant preoperative planning is required to minimize complications related to soft tissue and bone. Management of these fractures are not without complications such as infection and delayed union; hence these complications should be looked for at the earliest and treated accordingly. If principles of treatment are correctly followed, most of cases will have good final outcome with either modality of treatment for these fractures.

\section{References}

1. Stannard J, Schmidt A, Kregor P. Surgical treatment of orthopaedic trauma, $1^{\text {st }}$ edition 2007, 767-97.

2. Schatzker J, Tile $M$ The rationale of operative fracture care, 3rd edition. 475-76

3. Court Brown, Caesar B. Epidemiology of adult fractures: a review. Injury. 2006; 37:691-697.

4. Chapman MW. Fractures of the tibial and fibular shafts. In: Chapman's orthopaedic surgery.3rd edition, vol 1. Philadelphia: Lippincott Williams and Wilkins. 2001: 755-810.
5. Bourne RB. Pilon fractures of the distal tibia. Clin Orthop Relat Res. 1989; 240:42-46. [PubMed]

6. Bourne RB, Horabeck CH, Mac Nab BA. Intra-articular fractures of the distal tibia: the pilon fracture. J Trauma. 1983; 23:591-596. [PubMed]

7. Ovadia DN, Beals RK. Fractures of the tibial plafond. J Bone Jt Surg Am. 1986; 68:543-551.[PubMed]

8. Pollak AN, MC, Carthy ML, Bess RS. Outcomes after treatment of high-energy tibial plafond fractures. J Bone Jt Surg Am. 2003; 85:1893-1900. [PubMed]

9. Bedi A, Toan T, Karunakar M. Surgical Treatment of Nonarticular Distal Tibia Fractures. J Am Acad Orthop Surg. 2006; 14(7):406-16.

10. Oh W, Kyung S, Park H et al. Distal tibia metaphyseal fractures treated by percutaneous plate osteosynthesis. Clin Orthop. 2003; 408:286-291.

11. Collinge CA, Sanders RW. Percutaneous plating in the lower extremity. J Am Acad Orthop Surg. 2000; 8:211216. [PubMed]

12. Farouk O, Krettek C, Miclau T. Minimally invasive plate osteosynthesis and vascularity: preliminary results of a cadaver injection study. Injury. 1997; 28:7-12. [PubMed]

13. Merchant T, Dietz F. Long term follow up after fractures of the tibial and fibular shafts. J Bone Joint Surg Am. 1989; 71:599-606.

14. Johner R, Wruhs O. Cassification of tibial shaft fractures and correlation with results after rigid internal fixation. 
Clin Orthop 1983; 178:7-25.

15. Guo J, Tang N, Yang H, Tang T. A prospective, randomised trial comparing closed intramedullary nailing with percutaneous plating in the treatment of distal metaphyseal fractures of the tibia. J Bone Joint Surg Brit 2010; 92(7):984-988.

16. Robinson C, Mc Lauchlan J, Mc Lean I, Court-Brown. Distal metaphyseal fractures of the tibia with minimal involvement of the ankle. Classification and treatment by locked intramedullary nailing. J Bone Joint Surg Brit 1995; 77:781-87.

17. Ronga M, Longo U, Maffulli N. Minimally Invasive Locked Plating of Distal Tibia Fractures is Safe and Effective. Clin Orthop Relat Res. 2010; 468(4):975-982.

18. Borg T, Larsson S, Lindsjö U. Percutaneous plating of distal tibial fractures. Preliminary results in 21 patients. Injury. 2004; 35(6):608-14.

19. Collinge C, Kuper M, Larson K, Protzman R. Minimally Invasive Plating of High-Energy Metaphyseal Distal Tibia Fractures. J Orthop Trauma. 21(6):355-360.

20. Nork S, Schwartz A, Agel J, Holt S, Schrick J, Winquist R. Intramedullary nailing of distal metaphyseal tibial fractures". J Bone Joint Surg Am. 2005; 87(6):1213-21.

21. Ehlinger M, Adam P, Gabrion A, Jeunet L, Dujardin F, Asencio G. Sofcot Distal quarter leg fractures fixation: The intramedullary nailing alone option. Orthop Traumatol Surg Res. 2010; 96(6):674-82.

22. Oh W, Kyung S, Park H. et al. Distal tibia metaphyseal fractures treated by percutaneous plate osteosynthesis. Clin Orthop. 2003; 408:286-291.

23. Collinge C, Kuper M, Larson K, Protzman R Minimally Invasive Plating of High-Energy Metaphyseal Distal Tibia Fractures. J Orthop Trauma; 21(6):355-360.

24. Barie DP, Pilon fractures. In: Bucholz RW, Court-Brown CM, Heckman JD, Tornetta P Rockwood and Green's Fractures in Adults $20107^{\text {th }}$ edition Philadelphia Lippincott Williams and Wilkins. 1928-74. 